Abstracta Iranica

Revue bibliographique pour le domaine irano-aryen

Volume 32-33 | 2013

Comptes rendus des publications de 2009-2010

\title{
Israel Finkelstein. Kadesh Barnea: A Reevaluation of Its Archaeology and History
}

\section{Astrid Nunn}

\section{(2) OpenEdition}

10 Journals

Édition électronique

URL : http://journals.openedition.org/abstractairanica/40260

DOI : 10.4000/abstractairanica.40260

ISSN : 1961-960X

\section{Éditeur :}

CNRS (UMR 7528 Mondes iraniens et indiens), Éditions de l'IFRI

\section{Édition imprimée}

Date de publication : 1 décembre 2013

ISSN : 0240-8910

\section{Référence électronique}

Astrid Nunn, «Israel Finkelstein. Kadesh Barnea: A Reevaluation of Its Archaeology and History », Abstracta Iranica [En ligne], Volume 32-33 | 2013, document 67, mis en ligne le 01 juillet 2016, consulté le 21 décembre 2020. URL : http://journals.openedition.org/abstractairanica/40260 ; DOI : https:// doi.org/10.4000/abstractairanica.40260

Ce document a été généré automatiquement le 21 décembre 2020.

Tous droits réservés 


\title{
Israel Finkelstein. Kadesh Barnea: A Reevaluation of Its Archaeology and History
}

\author{
Astrid Nunn
}

\section{RÉFÉRENCE}

Israel Finkelstein. « Kadesh Barnea: A Reevaluation of Its Archaeology and History ». Tel Aviv, 2010/1, p. 111-125.

1 Ce site situé dans le nord-est du Sinai et identifié au Kadesh Barnea biblique remonte au début du Fer et est resté habité de manière ininterrompue jusqu'au IV ${ }^{e}$ s. av. J.-C. Au $\mathrm{VIII}^{\mathrm{e}} \mathrm{s}$. fut construite une forteresse (strates 3-2) liée à l'expansion assyrienne. Des vestiges perses se trouvent au-dessus de la strate 2 (post-Stratum 2 et Stratum 1).

\section{AUTEURS}

\section{ASTRID NUNN}

Université de Munich 